\title{
Serum 25-Hydroxy-Vitamin D and Vitamin B12 Levels in Childhood Alopesia Areata
}

Selcen Kundak ${ }^{\oplus}$ Ayşe Kutlu $\odot$

\author{
Alopesi Areatalı Çocuklarda Serum Vitamin D ve \\ Vitamin B12 Düzeyleri
}

\section{ABSTRACT}

Objective: Alopecia areata (AA); is a sudden onset, non-scaring hair loss. Twenty percent of cases are children.Although it is thought to be related to genetic predisposition, inflammation, immunological processes or psychological triggers, its pathophysiology is still not fully understood. This study was planned to investigate the levels of serum 25-hydroxy vitamin D, vitamin B12, thyroid-stimulating hormone (TSH) and free T4 FT4) in children with AA and compare the results with age-matched healthy individuals.

Methods: A retrospective medical record review was carried out in an outpatient dermatology clinic in a tertiary medical center between January 1,2013 and December 31, 2017. The study included 520 patients (ages 0-18 years) who received a clinical diagnosis of AA.106 patients with AA met the inclusion criteria. Patients in the control group $(n=106)$ were selected among children aged $0-18$ years without any medical and/or psychiatric diagnosis. Both past medical and family medical history were also noted. Results of laboratory tests including vitamin D, vitamin B12, TSH, FT4, and thyroid auto-antibodies were noted.

Results: There was no significant difference between the patient and control groups in terms of mean age. Mean age of onset was 8.0 years. The number of boys and girls in both the patient and control groups were 55 and 51. Serum levels of FT4 and TSH in patients with AA were significantly higher than the control group. Both vitamin $D$ and vitamin $B 12$ levels of the patients with $A A$ were significantly lower than the control group.

Conclusion: Although its role in etiopathogenesis is not understood, the importance of monitoring both vitamins and thyroid functions in childhood AA cases is obvious.

Keywords: Alopecia areata, Vitamin D, Vitamin B12, TSH, FT4

Öz

Amaç: Alopesi areata (AA); ani başlangıçlı, skar bırakmayan saç dökülmesidir. Olguların \%20'si çocuktur. Genetik yatkınlık, inflamasyon, immünolojik süreçler veya psikolojik tetikleyiciler ile ilişkili olduğu düşünülse de, patofizyolojisi hala tam olarak anlaşılamamıştır. Bu çalışma; alopesi areatalı çocuklarda vitamin D, vitamin B12, tiroid stimulan hormon (TSH) ve serbest T4 (fT4) düzeylerini araştırmak ve sonuçları aynı yaş grubundaki sağlıklı bireylerle karşılaştırmak için planlandı.

Yöntem: 1 Ocak 2013 ve 31 Aralık 2017 tarihleri arasında üçüncü basamak sağlık merkezinde dermatoloji kliniğine ayaktan başvuran hastalarda tek merkezli retrospektif tıbbi kayıt incelemesi yapıldı. Çalışmaya klinik tanısı alopesi areata (AA olan 520 hasta (0-18 yaş) çalışmaya alındı. AA'lı 106 hasta dahil edilme kriterlerini karşıladı. Kontrol grubundaki hastalar $(n=106)$ herhangi bir tıbbi ve/veya psikiyatrik tanısı olmayan 0-18 yaş arası çocuklar arasından seçildi. Hem tıbbi geçmişleri hem de aile tıbbi geçmişleri kaydedildi. 25 hidroksi-D vitamini, B12 vitamini, TSH, FT4 ve tiroid oto-antikorlarını içeren laboratuvar testlerinin sonuçları kaydedildi.

Bulgular: Hasta ve kontrol grubu arasında ortalama yaş açısından anlamlı fark yoktu. Ortalama başlangıc yaşı 8 idi. Hem hasta hem de kontrol grubundaki kız ve erkeklerin sayısı 55 ve 51'dir. AA hastalarında serum FT4 ve TSH düzeyleri kontrol grubuna göre anlamlı olarak yüksek bulundu. AA'lı hastaların hem D vitamini hem de B12 vitamini düzeyleri kontrol grubundan anlamlı olarak düşüktü.

Sonuç: Etyopatogenezdeki rolü henüz anlaşılmamış olsa da, çocukluk çağı $A A$ vakalarında hem $D$ hem de B12 vitaminlerini ve tiroid fonksiyonlarını izlemek önemlidir.

Anahtar kelimeler: Alopesi areata, Vitamin D, Vitamin B12, TSH, FT4
Received: 20.11 .2020

Accepted: 09.12.2020

Published Online: 30.04 .2021

Cite as: Kundak S, Kutlu A. Serum 25-HydroxyVitamin D and vitamin B12 levels in childhood alopesia areata. İzmir Dr. Behçet Uz Çocuk Hast. Dergisi. 2021;11(1):101-7.

Selcen Kundak

S.B.Ü. Dr. Behçet Uz Çocuk Hastalıkları ve Cerrahisi Eğitim ve Araştırma

Hastanesi

İzmir, Türkiye drselcen@yahoo.com.tr ORCID: 0000-0001-6061-925X

A. Kutlu 0000-0001-9359-6162

S.B.Ü. Dr. Behçet Uz Çocuk Hastalıkları ve Cerrahisi Eğitim ve Araştırma Hastanesi izmir, Türkiye 


\section{INTRODUCTION}

Alopecia areata (AA) is a tissue-specific autoimmune disease. It constitutes $0.7 \%-3.8 \%$ of all dermatoses encountered in dermatology practice. Its estimated lifetime risk of occurrence ranges between 1.7\% -2\% $(1,2)$. AA is mainly a T-cell mediated autoimmune disease of hair follicles. Circulating macrophages and Langerhans cells may also target hair follicles ${ }^{(3,4)}$. Accumulation of CD4 + T cells around the hair follicles supports the autoimmune origin of the disease. Abnormal expression levels of HLA I and II and its coexistence with other dermatoses are findings that reinforce autoimmune etiology of $A A^{(5,6)}$.

Apart from autoimmunity, many possible etiologic factors have been suggested for AA. High rates of familial transmission of AA suggest a genetic background. Indeed, at least one first-degree relative of $25 \%$ of the children with AA has been reported in the literature ${ }^{(4)}$. Vitamins and thyroid hormones are among the other markers investigated as possible etiological factors of AA. Due to their fundamental role in innate and acquired immunity, vitamin $D$, vitamin B12 and thyroid hormones have been investigated in many autoimmune and inflammatory diseases including AA. The 25 -hydroxy vitamin D acts by binding to its receptors in the cell nuclei. The presence of vitamin $D$ receptor in hair follicles, dermal papilla, and keratinocytes revealed the possible relationship between vitamin $D$ levels and hair growth ${ }^{(7,8)}$. Although not as much as vitamin D, cobalamin (vitamin B12) is also involved in the development of hair follicles. As a coenzyme, vitamin B12 contributes to nucleic acid production in the proliferative phase of hair follicles ${ }^{(9)}$. Similarly, the role of thyroid hormones in hair stem cell development and hair cycle has suggested that T3 and T4 levels may be important in the etiopathogenesis of $A A^{(10)}$.

In order to reveal the possible relationship between serum levels of vitamins, thyroid hormones and AA, many studies have been conducted in adult individuals ${ }^{(11,12)}$. Nevertheless, there are few studies investigating the relationship between $A A$ and these parameters in pediatric cases. In this respect, our study has a critical importance. Therefore, the current study was planned to investigate the serum levels of 25-hydroxy vitamin D, vitamin B12, TSH, and FT4 in children with AA and age-matched healthy controls.

\section{MATERIALS and METHODS}

We retrospectively reviewed the medical records of 520 patients diagnosed with AA who were followed up at the dermatology outpatient clinic of the University of Health Sciences Dr. Behçet Uz Child Disease and Pediatric Surgery Training and Research Hospital, between January 1, 2013 and December 31, 2017. Out of 520 patients, 106 patients met the inclusion criteria. Records of 106 patients diagnosed with AA between the ages of 0-18 in our dermatology outpatient clinic were included in the study. In order to increase the homogeneity of the study group and to exclude factors that may affect the results, very strict inclusion criteria were applied. The main inclusion criterion was the absence of any psychiatric problem. For this reason, all children diagnosed with AA were subjected to psychiatric evaluation. In the child psychiatry consultation, those who did not have any psychiatric disease or a psychogenic trigger before the onset of the disease were included in the study. Other criteria for inclusion in the study were as follows: (i) alopecia areata should be the first episode, (ii) the lesion should involve less than 25\% of the scalp. All lesions were on the scalp and Severity of Alopecia Tool (SALT) score was used to evaluate disease severity according to the extent of hair loss (S0: no hair loss; S1: <25\%; S2: 25\%-49\%; S3: 50\%-74\%; S4: 75\%-99\%; and S5: $100 \%$ scalp hair loss), (iii) disease duration < 1 year, (iv) and lack of any additional skin disease and history of family skin disease such as alopecia areata, vitiligo, or psoriasis, etc. The patients with abnormal thyroid function test results or anti-T or anti-M antibody levels in the AA or control groups were excluded from the study.

Patients in the control group were selected among children aged 0-18 years without any medical and/or psychiatric diagnosis. The number and gender distribution of the patients in the control group were similar to those of the patient group. The data 
Table 1. Serum levels of vitamin D, vitamin B12 and thyroid hormones in cases with AA and controls.

\begin{tabular}{lcccr}
\hline Parameters & $\begin{array}{c}\text { SAMPLING } \\
\text { AA/Control }\end{array}$ & $\begin{array}{c}\text { AA } \\
\text { Median (min-max) }\end{array}$ & $\begin{array}{c}\text { CONTROL } \\
\text { Median (min-max) }\end{array}$ & $\mathbf{z}$ \\
\hline Age (years) & $106 / 106$ & $8.03(1.3-17.3)$ & $8.0(3.08-16.16)$ & -0.703 \\
FT4 (ng/dL) & $103 / 77$ & $1.09(0.06-1.39)$ & $1.06(0.78-1.42)$ & -2.140 \\
TSH (mlU/L) & $103 / 77$ & $1.99(0.51-5.61)$ & $1.56(0.63-3.97)$ & -2.242 \\
D vit ( $\mu$ g/L) & $106 / 106$ & $20.8(5.9-42.3)$ & $25.0(15.3-48.2)$ & -4.941 \\
B12 vit (ng/L) & $103 / 72$ & $364(142-937)$ & $429(207-983)$ & -2.984 \\
\hline
\end{tabular}

collection was approved by the local ethics committee (University of Health Sciences Dr. Behçet Uz Child Disease and Pediatric Surgery Training and Research Hospital Local Ethics Committee/374). The data on biochemical and hormonal tests were obtained from the medical records. Past laboratory records were examined and serum levels of FT4, TSH, vitamins D and $\mathrm{B} 12$ were determined. For homogenity in terms of vitamin $D$ levels the results obtained during summer period in the patient and control groups were evaluated. Concentrations of 25-hydroxy vitamin D (lower limit; $15 \mu \mathrm{g} / \mathrm{L}$ ), vitamin B12 (lower limit; $187 \mathrm{ng} / \mathrm{L}$ ), TSH (lower limit; $0.54 \mathrm{mIU} / \mathrm{L}$ ) and FT4 (lower limit; $0.7 \mathrm{ng} / \mathrm{dL}$ ) were determined using electro-chemiluminescence immunoassay (ECLIA) method.

\section{Statistical analysis}

Statistical analyses were performed by using SPSS 20.0 software (SPSS Inc. Chicago, IL, USA). Descriptive statistics were used to define demographic and clinical variables of all participants. Categorical variables were compared with chi-square test. The normality of the data distribution was checked with the Kolmogorov-Smirnov test. Since the distribution of the sample group was not normal, Mann-Whitney $U$ test was performed in binary comparisons. The $p<0.05$ was considered as statistically significant.

\section{RESULTS}

Gender distribution was equal in both patient and control groups. Both the patient, and the control groups consisted of 55 boys, and 51 girls There was no significant difference between the patient and control groups in terms of mean age. Median age of
AA patients was 8.0 years. Although the cases with normal TFT results in the patient and control groups were included in the study, serum levels of FT4 and TSH in patients with AA were significantly higher than the control group. Both vitamin D and vitamin B12 levels of the patients with AA were significantly lower than the control group (Table 1).

Lower limits of reference values of our laboratory were $187 \mathrm{ng} / \mathrm{L}$ for vitamin B12, and $15 \mu \mathrm{g} / \mathrm{L}$ for vitamin $D$ (patients with available summer period measurements were included in the study). The patient and the control groups were compared in terms of vitamin B12 and vitamin D deficiencies. In the AA group $7(7 / 103)$ patients had vitamin B12 levels below $187 \mathrm{ng} / \mathrm{L}$, while vitamin B12 deficiency was not detected in the healthy group (0/72). The number of patients with vitamin B12 deficiency in the AA group was significantly higher than the control group $\left(\chi^{2}: 5.097 p=0.024\right)$. When the study participants were grouped according to their vitamin B 12 levels, 30 patients $(30 / 103)$ in the $A A$, and 7 $(7 / 72)$ patients in the control group had vitamin B12 levels below $300 \mathrm{ng} / \mathrm{L}$. As a result, the number of patients with vitamin B12 levels below 300 in the AA group was significantly higher than the control group $\left(\chi^{2}=6.764 p=0.009\right)$.

Considering the vitamin $D$ values of the groups, in the AA group 25 (25/106) patients had vitamin D levels below $15 \mu \mathrm{g} / \mathrm{L}$, whereas none of the cases in the control group had vitamin $D$ values below 15 $\mu \mathrm{g} / \mathrm{L}(0 / 106)$. The number of patients with vitamin $D$ deficiency was significantly higher in the AA group compared to the control group $\left(\chi^{2}: 28,342\right.$ $\mathrm{p}<0,0001)$.

The presence of thyroid disease and absence of autoimmune thyroiditis were the study inclusion 
criteria. Even when TSH and FT4 values were within normal limits, both FT4 and TSH levels were statistically significantly higher in the AA group compared to the control group $(n=103 / 77 ; z=-2,140$, $p=0.032 ; z=-2.224, p=0.025$ )

\section{DISCUSSION}

Alopecia areata $(A A)$ is a common autoimmune disorder which is characterized by sudden onset of focal well-circumscribed hair loss without signs of significant inflammation and scarring. In the literature, various hypotheses related to etiopathogenesis of AA are encountered. One of the most accepted hypotheses is the "immune privilege collapse" hypothesis. Healthy hair follicle epithelium does not express major histocompatibility complex (MHC) class I and II molecules ${ }^{(13,14)}$. For this reason, the hair follicle is considered as an immune privileged area. The mechanism that initiated the presentation of various antigens in the anagen phase hair follicle epithelium to $T$ cells by antigen presenting cells is still unknown. The loss of the immune privilege of the anagen hair bulb is important in AA pathogenesis. IFN- $\nu$ which is a proinflammatory cytokine is prominently expressed in lesional skin of the patients with $A A^{(14-16)}$. It is thought that IFN- $\gamma$ induces the expression of $\mathrm{MHC}$ class I molecules and triggers the presentation of autoantigens. The autoantigens presented from the anagen hair follicle structure are recognized by $\mathrm{C} 8+\mathrm{T}$ lymphocytes, then the attack to the anagen hair follicle epithelium begins with the help of CD4 + T lymphocytes ${ }^{(15-17)}$. Because CD8 + T lymphocytes are cytotoxic, their presence in the hair follicle interrupts hair growth easily with resultant development of inflammatory process ${ }^{(14,16-19)}$. It has been shown in many studies that vitamin $D$ impedes the secretion of proinflammatory cytokines and inhibits inflammation by restraining Th1 and Th17 cells. There is an increase in proinflammatory cytokines, especially IFN- $\gamma$, in vitamin $\mathrm{D}$ deficiency ${ }^{(14,15)}$. Vitamin D may contribute to maintenance of the immune privilege by decreasing the production of IFN- $\gamma$. Additionally, triggers such as emotional stresses, minor skin traumas, infectious agents also seem likely to cause an intrafollicular increase in IFN- $\gamma$ on the background of genetic susceptibility $(14,15,17,20-25)$.

A second hypothesis is the production of autoantibodies specific to the hair follicle. IL 6 is a proinflammatory cytokine that increases in vitamin $D$ deficiency ${ }^{(13)}$. IL 6 induces an increase in IgG. The presence of autoantibodies specific to hair follicles does suggest that such autoantibodies may provide clues as to the antigenic targets for T cells. Vitamin D has been shown to inhibit the conversion of B cell precursors to plasma cells and to modulate humoral immunity ${ }^{(15,17,22)}$.

As is seen, vitamin D deficiency can trigger AA through many mechanisms of the immune system. Studies have shown the presence of a relationship between vitamin $D$ deficiency and autoimmune disease ${ }^{(15,17)}$. Vitamin D supplementation improves the immune response by inhibiting Th1 cell activity in AA ${ }^{(23)}$. Although there is strong evidence that vitamin $D$ is both anti-inflammatory and immunoregulatory ${ }^{(23,26,27)}$, the mechanism of its effect on autoimmunity is not understood ${ }^{(26-28)}$. Low levels of vitamin $D$ have also been found in many autoimmune diseases ${ }^{(26-32)}$.

A collapse in immune-privilege environment of the hair follicle initiates the development of $A^{(23,27)}$. Similarly, the lack of micronutrients impairs the normal course of hair follicle cycles ${ }^{(27,33)}$. There are multiple reasons to suspect a role for vitamins in rapidly dividing hair follicle. Given their role in the development of a normal hair follicle and in immune cell function (27), a growing number of investigations have sought to determine whether serum levels of 25-hydroxy vitamin D and vitamin B12 may differ in children with AA. Studies have demonstrated relations between vitamin $D$ deficiency and autoimmune disease ${ }^{(23)}$. Vitamin D supplementation improves the immune response by inhibiting Th1 cell activity in $A A^{(23)}$. Decreased levels of vitamin $D$ in cases with systemic lupus and rheumatoid arthritis support the relationship between autoimmunity and this vitamin ${ }^{(34,35)}$.

Studies investigating serum levels of vitamin $D$ in patients with $A A$ have reported that serum vitamin $D$ 
levels were significantly lower in AA patients compared to healthy controls ${ }^{(36,37)}$ Similar to other studies in the literature, in our study, vitamin D levels of AA cases were found to be significantly lower than controls. Vitamin $D$ levels were found to be less than $15 \mu \mathrm{g} / \mathrm{L}$ in 25 of 106 patients with AA (25/106). In the control group, none of the study participants had vitamin D values below $15 \mu \mathrm{g} / \mathrm{L}(0 / 106)$. Most studies reported low levels of vitamin $D$ in both summer and winter periods ${ }^{(36,37)}$. In our study, summer values of vitamin $\mathrm{D}$ were taken into account and relatively lower levels were noted. In contrast to previous studies, Thompson et al. found no association between AA development and high or low vitamin D levels. In addition, they reported that vitamin D supplementation did not prevent development of $A A^{(28)}$.

In contrast to vitamin $D$, there is limited evidence to suggest that vitamin B12 levels decrease or increase in AA cases. In terms of vitamin B12, a possible relation between $A A$ and vitamin $B 12$ deficiency is predicated on the autoimmune nature of pernicious anemia. In the present study, in the control group none of the cases (0/72), while in the AA group 7 (103) patients had vitamin B12 values below $187 \mathrm{ng} / \mathrm{L}$. In contrast to our study, studies investigating possible relationship between vitamin B12 levels and AA did not identify any such differences in vitamin B12 levels of patients compared to control subjects ${ }^{(12,38)}$. Concordantly, Ertugrul et al. measured holotranscobalamine, vitamin B12, folate and homocysteine levels in 75 patients with $A A$ and control subjects. They did not find any significant differences between two groups regarding these parameters. The current literature failed to show the relationship between vitamin B12 deficiency and AA, but our study was the first with the largest sample in childhood and found that vitamin B12 levels in children diagnosed with AA were significantly lower than healthy ones. Vitamin B12 deficiency was also found statistically significantly more often in children with AA. More research seems to be needed to understand the relationship between vitamin B12 and AA.

In addition to autoimmune and genetic predisposition AA has been linked to thyroid disorders (39). Thyroid hormones are known to play an important role in the synthesis of mesenchymal stem cells located at the base of hair follicles. Both T3 and T4 hormones induce hair follicle stem cell niche and contribute to renewed life cycle of the hair follicle (10). Hence, the close relationship between the hair follicle and thyroid hormones suggests that one of the underlying causes of the development of AA may be thyroid diseases.

The incidence of thyroid disease varies in patients with AA. However, despite the high prevalence of thyroid disease in patients with $A A$, no clear association was noted between thyroid dysfunction and the type and severity of AA. Moreover, no relation was found between thyroid disorders and family or medical history of subjects with $A A{ }^{(40)}$. In the current study, we found that serum levels of TSH and FT4 were significantly higher in AA group than in the control group. Increased serum TSH and FT4 levels may contribute to the development of AA. However, since there is no significant correlation between AA outcomes and TSH and FT4 levels, it is not rational to perform thyroid fuction tests routinely. Our suggestion is supported by other studies. Hollowell et al. reported that TFT results were abnormal in 10 to $15 \%$ of healthy individuals ${ }^{(41)}$. Similarly, Patel et al. reported that routine thyroid function screening should be restricted to AA patients with a history of Down syndrome or atopy, a family history of thyroid disorders, or clinical findings of thyroid dysfunction ${ }^{(11)}$.

Current study has consistently demonstrated lower vitamin D and vitamin B12 levels in patients with AA. Although present study is limited by its retrospective nature and single-center site, our results showed statistically significant decrease in vitamin D and vitamin B12 levels but significant increase in circulating TSH and FT4 levels in participants with AA. Overall, present study revealed an association between vitamin D and B12 status and risk of developing $A A$.

Ethics Committee Approval: SBÜ. Izmir Dr. Behçet Uz Children's Diseases Training and Research Hospital has been approved by the Clinical Research Ethics Committee (27.02.20 / 36). 


\section{Conflict of Interest: None.}

Funding: No funding or sponsorship was received for this study or publication of this article.

Informed Consent: Written informed consent is obtained from the parents of every patient.

\section{REFERENCES}

1. Alkhalifah A. Alopecia areata update. Dermatologic clinics 2013;31:93-108.

https://doi.org/10.1016/j.det.2012.08.010

2. Gilhar A, Etzioni A, Paus R. Alopecia areata. The New England journal of medicine 2012;366:1515-25. https://doi.org/10.1056/NEJMra1103442

3. Safavi KH, Muller SA, Suman VJ, Moshell AN, Melton LJ, 3rd. Incidence of alopecia areata in Olmsted County, Minnesota, 1975 through 1989. Mayo Clinic proceedings 1995;70:62833.

https://doi.org/10.4065/70.7.628

4. Wohlmuth-Wieser I, Osei JS, Norris D, Price V, Hordinsky MK, Christiano A, et al. Childhood alopecia areata-Data from the National Alopecia Areata Registry. Pediatric dermatology 2018;35:164-9. https://doi.org/10.1111/pde.13387

5. Alkhalifah A, Alsantali A, Wang E, McElwee KJ, Shapiro J. Alopecia areata update: part I. Clinical picture, histopathology, and pathogenesis. Journal of the American Academy of Dermatology 2010;62:177-88, quiz 189-190. https://doi.org/10.1016/j.jaad.2009.10.032

6. McElwee KJ, Gilhar A, Tobin DJ, Ramot Y, Sundberg JP, Nakamura $M$, et al. What causes alopecia areata? Experimental dermatology 2013;22:609-26. https://doi.org/10.1111/exd.12209

7. Boucher BJ. Curcumin and diabetes: a role for the vitamin $D$ receptor? The British journal of nutrition 2012;108:2104. https://doi.org/10.1017/S0007114512004825

8. Daroach M, Narang T, Saikia UN, Sachdeva N, Sendhil Kumaran M. Correlation of vitamin D and vitamin D receptor expression in patients with alopecia areata: a clinical paradigm. International journal of dermatology 2018;57:21722.

https://doi.org/10.1111/ijd.13851

9. Hunt A, Harrington D, Robinson S. Vitamin B12 deficiency. BMJ (Clinical research ed) 2014;349:g5226. https://doi.org/10.1136/bmj.g5226

10. Contreras-Jurado C, Lorz C, García-Serrano L, Paramio JM, Aranda A. Thyroid hormone signaling controls hair follicle stem cell function. Molecular biology of the cell 2015;26:126372.

https://doi.org/10.1091/mbc.E14-07-1251

11. Patel D, Li P, Bauer AJ, Castelo-Soccio L. Screening Guidelines for Thyroid Function in Children With Alopecia Areata. JAMA Dermatology 2017;153:1307-10. https://doi.org/10.1001/jamadermatol.2017.3694

12. Ertugrul DT, Karadag AS, Takci Z, Bilgili SG, Ozkol HU, Tutal E, et al. Serum holotranscobalamine, vitamin B12, folic acid and homocysteine levels in alopecia areata patients. Cutaneous and Ocular Toxicology 2013;32:1-3. https://doi.org/10.3109/15569527.2012.683499

13. Rossi A, Cantisani C, Carlesimo M, Scarnò M, Scali E, Mari E, et al. Serum concentrations of IL-2, IL-6, IL-12 and TNF- $\alpha$ in patients with alopecia areata. International journal of immunopathology and pharmacology 2012;25:781-8. https://doi.org/10.1177/039463201202500327

14. Wang E, McElwee KJ. Etiopathogenesis of alopecia areata: Why do our patients get it? Dermatologic therapy 2011;24:337-47. https://doi.org/10.1111/j.1529-8019.2011.01416.x

15. Ersoy-Evans S. Commentary: Vitamin D and autoimmunity: is there an association? Journal of the American Academy of Dermatology 2010;62:942-4. https://doi.org/10.1016/j.jaad.2010.02.009

16. Juarez-Rendón KJ, Rivera Sanchez G, Reyes-Lopez M, GarcíaOrtiz JE, Bocanegra-García V, Guardiola-Avila I, et al. Alopecia Areata. Current situation and perspectives. Archivos argentinos de pediatria 2017;115:e404-e411. https://doi.org/10.5546/aap.2017.eng.e404

17. Hewison $M$. An update on vitamin $D$ and human immunity. Clinical endocrinology 2012;76:315-25. https://doi.org/10.1111/j.1365-2265.2011.04261.x

18. Anzai A, Wang EHC, Lee EY, Aoki V, Christiano AM. Pathomechanisms of immune-mediated alopecia. International immunology 2019;31:439-47. https://doi.org/10.1093/intimm/dxz039

19. Hordinsky MK. Overview of alopecia areata. The journal of investigative dermatology Symposium proceedings 2013;16:S13-15. https://doi.org/10.1038/jidsymp.2013.4

20. Tabara K, Kozłowska M, Jędrowiak A, Bienias W, Kaszuba A. Serum concentrations of selected proinflammatory cytokines in children with alopecia areata. Postepy dermatologii i alergologii 2019;36:63-9. https://doi.org/10.5114/ada.2019.82826

21. Erpolat S, Sarifakioglu E, Ayyildiz A. 25-hydroxyvitamin D status in patients with alopecia areata. Postepy dermatologii i alergologii 2017;34:248-252. https://doi.org/10.5114/ada.2017.67847

22. Gade VKV, Mony A, Munisamy M, Chandrashekar L, Rajappa $M$. An investigation of vitamin D status in alopecia areata. Clinical and experimental medicine 2018;18:577-84. https://doi.org/10.1007/s10238-018-0511-8

23. Antico A, Tampoia M, Tozzoli R, Bizzaro N. Can supplementation with vitamin $D$ reduce the risk or modify the course of autoimmune diseases? A systematic review of the literature. Autoimmunity reviews 2012;12:127-36. https://doi.org/10.1016/j.autrev.2012.07.007

24. Lin X, Meng X, Song Z. Vitamin D and alopecia areata: possible roles in pathogenesis and potential implications for therapy. American journal of translational research 2019;11:5285-300.

25. Siddappa H, Kumar YHK, Vivekananda N. Evaluation of Association of Vitamin D in Alopecia Areata: A Case-control Study of 100 Patients in a Tertiary Rural Hospital of Southern India. Indian dermatology online journal 2019;10:45-9.

26. Thompson JM, Mirza MA, Park MK, Qureshi AA, Cho E. The Role of Micronutrients in Alopecia Areata: A Review. American journal of clinical dermatology 2017;18:663-79. https://doi.org/10.1007/s40257-017-0285-x

27. Almohanna,HM, Ahmed AA, Tsatalis JP, Tosti A.. The role of vitamins and minerals in hair loss: a review. Dermatology and therapy, 2019;9(1):51-70. https://doi.org/10.1007/s13555-018-0278-6

28. Thompson JM, Li T, Park MK, Qureshi AA, Cho E. Estimated serum vitamin $D$ status, vitamin $D$ intake, and risk of incident alopecia areata among US women. Archives of dermatological 
research 2016;308:671-6. https://doi.org/10.1007/s00403-016-1687-y

29. Djeraba Z, Benlabidi F, Djaballah-Ider FZ, Medjeber O, ArroulLammali A, Belguendouz H, et al. Vitamin D status in Algerian Behçet's disease patients: an immunomodulatory effect on NO pathway. Immunopharmacology and immunotoxicology 2017;39:243-50.

https://doi.org/10.1080/08923973.2017.1327967

30. Vasile M, Corinaldesi C, Antinozzi C, Crescioli C. Vitamin D in autoimmune rheumatic diseases: A view inside gender differences. Pharmacological research 2017;117:228-41. https://doi.org/10.1016/j.phrs.2016.12.038

31. Wang LM, Zheng ZH, Li TF, Han LS, He YJ, Zhang YL, et al. 25-hydroxyvitamin $D$ is associated with metabolic syndrome among premenopausal women with systemic lupus erythematosus in China. Lupus 2017;26:403-9. https://doi.org/10.1177/0961203316668040

32. Zhang $X$, Wang W, Li Y, Wang H, Liu R, Zhu L. Serum 25-hydroxyvitamin D status in chinese children with vitiligo: a case-control study. Clinical pediatrics 2018;57:802-5. https://doi.org/10.1177/0009922817734362

33. Handjiski BK, Eichmüller S, Hofmann U, Czarnetzki BM, Paus R. Alkaline phosphatase activity and localization during the murine hair cycle. The British journal of dermatology 1994;131:303-10. https://doi.org/10.1111/j.1365-2133.1994.tb08515.x

34. Aguado P, del Campo MT, Garcés MV, González-Casaús ML, Bernad M, Gijón-Baños J, et al. Low vitamin D levels in outpatient postmenopausal women from a rheumatology clinic in Madrid, Spain: their relationship with bone mineral density. Osteoporosis international : a journal established as result of cooperation between the European Foundation for Osteoporosis and the National Osteoporosis Foundation of the USA 2000;11:739-44. https://doi.org/10.1007/s001980070052
35. Kamen DL, Cooper GS, Bouali H, Shaftman SR, Hollis BW, Gilkeson GS. Vitamin D deficiency in systemic lupus erythematosus. Autoimmunity reviews 2006;5:114-7. https://doi.org/10.1016/j.autrev.2005.05.009

36. Bakry OA, El Farargy SM, El Shafiee MK, Soliman A. Serum Vitamin D in patients with alopecia areata. Indian dermatology online journal 2016;7:371-7. https://doi.org/10.4103/2229-5178.190504

37. Mahamid M, Abu-Elhija O, Samamra M, Mahamid A, Nseir W. Association between vitamin $D$ levels and alopecia areata. The Israel Medical Association journal: IMAJ 2014;16:367-70.

38. Kalkan G, Yigit S, Karakuş N, Ateş O, Bozkurt N, Ozdemir A, et al. Methylenetetrahydrofolate reductase C677T mutation in patients with alopecia areata in Turkish population. Gene 2013;530:109-12. https://doi.org/10.1016/j.gene.2013.08.016

39. Wasserman D, Guzman-Sanchez DA, Scott K, McMichael A. Alopecia areata. International journal of dermatology 2007;46:121-31. https://doi.org/10.1111/j.1365-4632.2007.03193.x

40. Seyrafi H, Akhiani M, Abbasi H, Mirpour S, Gholamrezanezhad A. Evaluation of the profile of alopecia areata and the prevalence of thyroid function test abnormalities and serum autoantibodies in Iranian patients. BMC dermatology 2005;5:11.

https://doi.org/10.1186/1471-5945-5-11

41. Hollowell JG, Staehling NW, Flanders WD, Hannon WH, Gunter EW, Spencer CA, et al. Serum TSH, T(4), and thyroid antibodies in the United States population (1988 to 1994): National Health and Nutrition Examination Survey (NHANES III). The Journal of clinical endocrinology and metabolism 2002;87:489-99.

https://doi.org/10.1210/jcem.87.2.8182 